detected from $47 \%$ (21/45) during the 3 -month period immediately after vaccine introduction (March 2006-May $2006)$ to $100 \%(11 / 11)$ during the same 3 -month period 1 year after the vaccine introduction (March 2007-May 2007) (4). We believe that our findings are consistent with results of field trials that indicated that the vaccine provided relatively less protection against $\mathrm{P}[4]$ G2 strains than against other rotavirus strain types (5).

The beneficial impact of rotavirus vaccination in northeastern Brazil is reflected in the reduction of the detection rate of rotavirus among severe diarrhea cases in our study in Recife, which fell from $27 \%$ (45/166 cases) to $5.0 \%(11 / 221$ cases $)$ in the postvaccine 3-month reporting periods, respectively (4). Our data from Aracaju are indicative of heterotypic protection, although this is not statistically significant (1), against $\mathrm{P}[4] \mathrm{G} 2$ strains. Further postlicensure studies in Brazil are required to document continuing effectiveness of the national vaccination program as well as to closely monitor the circulating rotavirus strain types (6).

\section{Ricardo Queiroz Gurgel,*† Sarah Cristina Fontes Vieira,* Vanessa Cristiane Farias Barros, * Paula Brandão \\ Fontes, ${ }^{\star}$ Eduardo F. Salustino, * Osamu Nakagomi, Toyoko Nakagomi, $\ddagger$ Winifred Dove, $\uparrow$ \\ Nigel A. Cunliffe, $\dagger$ and Luis E. Cuevas†§}

*Federal University of Sergipe, Aracaju, Brazil; †University of Liverpool, Liverpool, UK; ‡Nagasaki University, Nagasaki, Japan; and §Liverpool School of Tropical Medicine, Liverpool, UK

\section{References}

1. Patel MM, de Oliveira LH, Bispo AM, Gentsch J, Parashar UD. Rotavirus P[4] $\mathrm{G} 2$ in a vaccinated population, Brazil [letter]. Emerg Infect Dis. 2008;14:863.
2. Linhares AC, Velázquez FR. Rotavirus $\mathrm{P}$ [4]G2 in a vaccinated population, Brazil [letter]. Emerg Infect Dis. 2008;14:864.

3. Gurgel RQ, Cuevas LE, Vieira SCF, Barros VCF, Fontes PB, Salustino ET, et al. Predominance of rotavirus $\mathrm{P}[4] \mathrm{G} 2$ in a vaccinated population, Brazil. Emerg Infect Dis. 2007;13:1571-3.

4. Nakagomi T, Cuevas LE, Gurgel RQ, Elrokhsi SH, Belkhir YA, Abugalia M, et al. Apparent extinction of non-G2 rotavirus strains from circulation in Recife, Brazil, after the introduction of rotavirus vaccine. Arch Virol. 2008;153:591-3.

5. Ruiz-Palacios GM, Perez-Schael I, Velazquez FR, Abate H, Breuer T, Clemens $\mathrm{SC}$, et al. Safety and efficacy of an attenuated vaccine against severe rotavirus gastroenteritis. N Engl J Med. 2006;354:1122.

6. Rotavirus vaccines. Wkly Epidemiol Rec. 2007;82:285-96.

Address for correspondence: Ricardo Gurgel, Federal University of Sergipe-Medicine Post Graduation Nucleus, Rua Claudio Batista S/N Bairro Sanatorio, Aracaju Sergipe 49000 100,

Brazil; email: ricardoqg@infonet.com.br

\title{
Erratum: Vol. 14, No. 4
}

In the article "Reassortant Avian Influenza Virus (H5N1) in Poultry, Nigeria, 2007" by I. Monne et al., the author affiliations contained errors. Isabella Monne, Tony M. Joannis, Alice Fusaro, Paola De Benedictis, Giovanni Cattoli, and Ilaria Capua are affiliated with Istituto Zooprofilattico Sperimentale delle Venezie, Legnaro, Padova, Italy.

We regret any confusion this error may have caused.

\section{EMERGING INFECTIOUS DISEASES}

The print journal is available at no charge to public health professionals

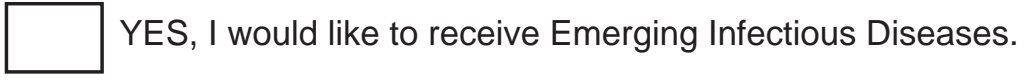

Please print your name and business address in the box and return by fax to 404-639-1954 or mail to

EID Editor CDC/NCID/MS D61 1600 Clifton Road, NE Atlanta, GA 30333

Moving? Please give us your new address (in the box) and print the number of your old mailing label here

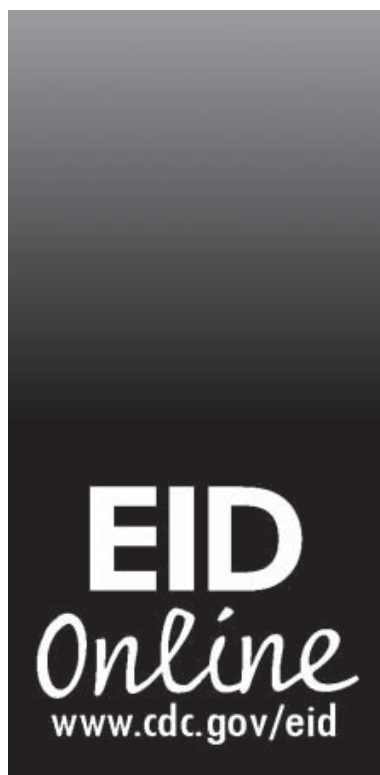

